\author{
Case Study \\ www.ijrap.net (ISSN:2229-3566)
}

\title{
PANCHANIDANATMAK ADHYAYANA OF STEVENS-JOHNSON SYNDROME: A CASE STUDY
}

\author{
Vasudha Sunil Umate ${ }^{1 *}$, Ashish Y. Gotmare ${ }^{2}$ \\ ${ }^{1}$ PG Scholar, Department of Roga Nidana Evum Vikriti Vigyan, Shri Ayurved Mahavidyalaya, Nagpur, \\ Maharashtra, India \\ ${ }^{2}$ Assistant Professor, Department of Roga Nidana Evum Vikriti Vigyan, Shri Ayurved Mahavidyalaya, Nagpur, \\ Maharashtra, India
}

Received on: 31/05/20 Accepted on: 30/06/20

\author{
*Corresponding author \\ E-mail: vasudhaumate07@gmail.com
}

DOI: $10.7897 / 2277-4343.110483$

\begin{abstract}
Stevens-Johnson syndrome (SJS) is a medical emergency which is characterized by skin and mucosal reaction to the use of certain drugs. It is a minor form of toxic epidermal necrolysis, with less than $10 \%$ body surface area (BSA) detachment. The purpose of reporting this case report is to study Stevens-Johnson syndrome in Ayurvedic perspective and correlate it with Ayurvedic Twacha vikara on the basis of samprapti adhyayana. A prediagnosed case of Stevens - Johnson syndrome by dermatologists was studied according to Ayurvedic diagnostic parameters i.e., Nidanapanchaka theory. The etiology and clinical features of Stevens-Johnson syndrome were correlated with twak-vikaras described in Samhitas. On clinical evaluation, the etiological factor found to be hypersensitivity to antibiotic drugs Azithromycin and Amoxicillin. It has been correlated as Asatmya-sevanahetu of Visarpa. The clinical symptoms were found correlated with Pittaja-Visarpa. Stevens-Johnson syndrome is a rare, emergency disorder of skin and mucous membrane that occurs secondary to use of certain drugs. The patient was told by the dermatologist about the prognosis of his condition and also became aware of the disadvantages of corticosteroid from some other sources. Hence, it is important to study such rare diseases in ayurvedic perspective to develop diagnostic and curative protocols to overcome limitations of contemporary medical science.
\end{abstract}

Keywords: Stevens - Johnson syndrome, Panchanidanatmak adhyayana, Pittaja-Visarpa, Anukta vyadhi.

\section{INTRODUCTION}

Stevens-Johnson syndrome (SJS) is a type IV (subtype C) hypersensitivity reaction that typically involves the skin and the mucous membranes. Although several classification schemes have been reported, the simplest classification breaks the disease down as follows ${ }^{1}$ :

1. Stevens-Johnson syndrome: A minor form of toxic epidermal necrolysis, with less than $10 \%$ body surface area (BSA) detachment

2. Overlapping Stevens-Johnson syndrome/Toxic Epidermal Necrolysis (TEN): Detachment of $10-30 \%$ of the BSA

3. Toxic epidermal necrolysis: Detachment of more than $30 \%$ of the BSA

It is a rare but serious systemic disorder- severe morbidity and even death affecting 7.1 per million people each year ${ }^{2}$. StevensJohnson etiology is mainly a reaction to medication. More than $80 \%$ of cases of SJS/TEN are drug related and $95 \%$ of TEN cases. Several drugs have been identified during the last decade as a triggering cause ${ }^{3}$ :

- NSAIDs, especially ibuprofen

- Anticonvulsants (phenytoin, valproic acid, phenobarbital, carbamazepine)

- Antibiotics (sulphonamides, aminopenicillins, quinolones, cephalosporin, tetracycline, imidazole antifungal agents)

- Allopurinol

- Corticosteroids
In Ayurveda, allergic manifestation is mentioned under the concept of satmya-asatmya ${ }^{4}$. It manifests due to exposure to asatmya ahara-vihara and contact with different poisonous materials (allergens). The factors are causing damage and disturbing dosha (dosha prakopa); which give displeasure or uneasiness to the body, are known as 'asatmya'.

Whenever the body comes in contact with any sort of asatmya regarding ahara, vihara or aushadha those result in manifestation of various diseases. The list of such asatmya hetujanya vyadhis also includes Visarpa. Visarpa is an acute inflammatory dermatological manifestation. It spreads very quickly like snake in various directions ${ }^{5}$. It is characterized by clinical features such as Aashu- anunnatashopha (quickly raised and subside), Daha (burning sensation), Jwara (fever) and Vedana (pain). The nature of Sphotas /Pidika (vesicles) is so specifically described as Agnidagdhavat (with intense burning sensation).

In the present case, etiology as well as symptoms of drug induced Stevens-Johnson syndrome was thoroughly studied, and efforts has been made to understand the condition in Ayurvedic perspective.

\section{Objectives}

1. To study Stevens - Johnson syndrome (SJS) in Ayurvedic perspective - Panchanidanatmak Adhyayana.

2. To correlate SJS with Ayurvedic Twacha vikara.

3. To establish Ayurvedic diagnostic criteria for modern dermatological diseases. 


\section{Case report}

\section{Chief complaints}

Complaints of macular rash all over body, blisters over lips, burning sensation all over body since last 2 days

\section{Associated complaints}

Patient was having complaints of Fever, Cough and Headache for 8 days.

\section{History of Present illness}

A 23 years old male patient working in pharmacy, of Vata- pittaja prakriti was admitted in one of the private hospitals at Nagpur with complaints of Burning sensation all over body, Blisters over lips, Macular rash all over body for last 2 days. Initially, he had felt slightly unwell for a few days and developed fever, cough, headache and generalized weakness for 8 days for which he took some medicines such as Azithromycin, Paracetamol, Acetaminophen, and Chlorpheniramine Maleate and Dextromethorphan, but did not get relief and the severity of fever and cough has increased. Then again, he consulted to general practitioner where he was prescribed with Amoxicillin, Levocetrizine, Montelukast and Ambroxol, Levosalbutamol, Guaifenesin combination.
While continuing the treatment for fever and cough, suddenly he noticed pinkish-red rash over trunk. There was severe burning sensation. Then the rash progressed over limbs including both palm and soles. Next day he observed there were blisters over his lips. The blisters gradually suppurated and burst. There was bleeding from burst blisters. The fever persisted, burning sensation increased, progression of rash increased.

\section{History of Past Illness}

No history of any major illness. No history of hypersensitivity to any drug.

\section{Family History}

No trait of any major illness in family.

\section{Personal history}

- Ahara- Vegan diet, 3 times /day, Sarvarasasatmya

- Vihara- Standing work, exposure to AC

- Nidra- Prakruta before the onset of symptoms and disturbed since few days

\section{RESULT}

Table 1: Ashta sthana Parikshana findings

\begin{tabular}{|c|c|}
\hline Ashta sthana Pariksha & Findings \\
\hline Naadi & Pittaja, Mandukagati \\
\hline Mala & 2-3 time /day, Alpamatra, Alpadravamala \\
\hline Mutra & 5-6 vega/Day, Pita varna, \\
\hline Jihwa & Sama \\
\hline Shabda & Deenavaak \\
\hline Sparsha & Ushna Sparsha \\
\hline Druk & Prakrut \\
\hline Akriti & Heenakaya \\
\hline
\end{tabular}

Table 2: Dashavidha Parikshana findings

\begin{tabular}{|c|c|}
\hline Dashavidha Pariksha & Analysis \\
\hline Prakruti & Vata-Pitta \\
\hline Vikriti & Pitta Pradhana Tridosha Vikriti \\
\hline Satwa & Madhyam \\
\hline Sara & Heena \\
\hline Samhanana & Heena \\
\hline Ahara Shakti & Jarana Shakti: Heena \\
\hline Vyayama Shakti & Heena \\
\hline Satmya & Madhyama \\
\hline Pramana & Heena kaya, Weight: 52 kg, Height: $162 \mathrm{~cm}$, BMI: 19.8 \\
\hline Vaya & Yuvavastha \\
\hline
\end{tabular}

\section{General Examination}

- General Condition- Moderate, Conscious, Alert

- Pallor- Present

- Icterus- Absent

- Cyanosis- Absent

- Clubbing- Absent

- Oedema- Absent

\section{Vital examination}

- Pulse rate- $120 / \mathrm{min}$

- Respiratory rate- $22 / \mathrm{min}$
- Blood pressure- $120 / 80 \mathrm{~mm}$ of $\mathrm{Hg}$

- Temperature- $101^{\circ} \mathrm{F}$

\section{Ayurvediya Twacha Roga Parikshana}

1. Varna- Tamra

2. Vistara- Mahavastu

3. Sthana- Sampurna Bahya Sharira Twacha

4. Swarupa- Mrudu, Sphutana, Tanu

5. Pidaka- Raktavarni, Raktapurita on Oshtha

6. Sparsha- Ushna, Swedana, Tivra Daha

7. Vedana- Satata, Todavata

8. Srava- Alpa Raktasrava 
9. Gandha- Visragandhi

10. Kandu- Alpa, Dahottara Kandu

11. Anya Lakshana- Swedana- Alpa sweda Angapatana- Absent Romaharsha- Absent Avastha- Nava, Ashukari

\section{Inspection of lesion}

A. Morphology

1) a) Primary lesion - Maculer Erythematous Rash over both lips

b) Secondary lesions - Redness, Blisters, Erosion

2) Shape - Slightly raised, Diffused

3) Color - Pinkish spots with center Red

B. Distribution- All over body - Trunk, All four Extremities, Lips

C. Configuration- Scattered

D. Other- Severe burning with Pain

Table 3: Panchanidanatmak Adhyayana of Stevens-Johnson syndrome

\begin{tabular}{|c|c|}
\hline Nidana-panchaka & Lakshana \\
\hline Hetu & $\begin{array}{c}\text { Asatmya (samyogaviruddha) dravya sevana }{ }^{6} \\
\text { (combine intake of different antibiotic drugs at once i.e., drug induced SJS- } \\
\text { Azithromycin + Augmentin + Dolokind) }\end{array}$ \\
\hline Purvarupa & Fever (Jwara) \\
& Cough (Kasa) \\
\hline Roopa & Fever (Jwara) \\
& Macular rash (Pitika) \\
& Tamra-Rakatavarniyapitika \\
& Burning Sensation (Daha) \\
& Pain (Shoola) \\
\hline Upashaya & Cold Sponging by Shitajala (Shitavatavaritarsho) \\
\hline
\end{tabular}

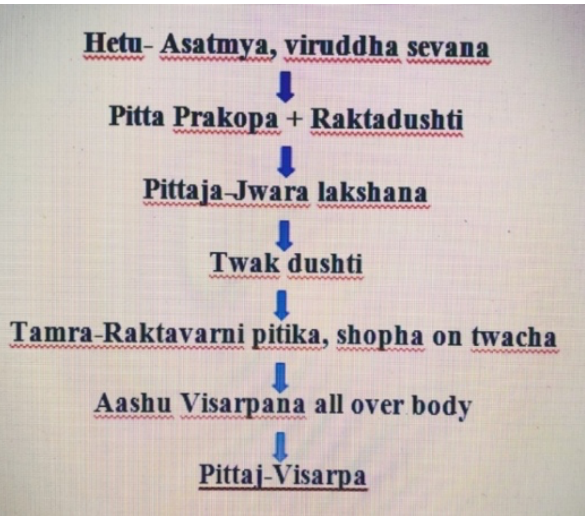

Samprapti Flow chart

Table 4: Samprapti Ghataka Adhyayana in present case

\begin{tabular}{|c|c|}
\hline \multicolumn{2}{|c|}{ Vikriti Pariksha : Samprapti Ghataka } \\
\hline Dosha & Pitta Pradhana tridosha \\
\hline Dushya & Rasa, Rakta \\
\hline Agni & Mandagni \\
\hline Agni dushti & Rasadhatwagni-mandya \\
\hline Srotas & Rasavaha, Raktavaha \\
\hline Srotodushti & Sanga, Vimargagaman \\
\hline Udbhavasthana & Madhya Sharir \\
\hline Vyaktasthana & Sarvasharira-Twacha \\
\hline Sancharasthana & Sarvasharira \\
\hline Rogamarga & Bahya \\
\hline Rogaswabhava & Ashukari \\
\hline Sadhya- Asadhyata & Kashtasaddhya \\
\hline
\end{tabular}

Table 5: Correlation of Stevens-Johnson syndrome and Visarpa

\begin{tabular}{|c|c|c|c|}
\hline \multirow[t]{2}{*}{ SJS } & \multicolumn{3}{|c|}{ Visarpa } \\
\hline & Charaka $^{7}$ & Sushruta $^{8}$ & Vagbhata $^{9}$ \\
\hline $\begin{array}{l}\text { The skin symptoms begin on the } \\
\text { face and chest, and then spread to } \\
\text { other parts of the body. }\end{array}$ & $\begin{array}{l}\text { Vividham Sarpatiiti Adhah- } \\
\text { Urdhwa- Tiryak } \\
\text { Sphota Shophadibhih } \\
\text { Prasarati }\end{array}$ & $\begin{array}{c}\text { Twak Mamsa Shonitagatah Sarvangasarinam } \\
\text { Asthit Atmalikga Vistruta- Anunnata- } \\
\text { Ashushopham Sarvato Visaranat }\end{array}$ & $\begin{array}{c}\text { Prakopaneih Prakupita } \\
\text { Visheshena Vidahibhih Dehe } \\
\text { Shighram Visarpanti }\end{array}$ \\
\hline
\end{tabular}


Table 6: Correlation of Stevens-Johnson syndrome and Pittaja Visarpa

\begin{tabular}{|c|c|c|c|c|}
\hline S. No. & SJS & Charaka $^{10}$ & Sushruta $^{11}$ & Vagbhata $^{12}$ \\
\hline 1 & Begins with fever & Jwara & Jwara & Jwara \\
\hline 2 & Body aches & Angabheda & - & - \\
\hline 3 & Headache & Shiroruja & - & - \\
\hline 4 & Tiredness, general ill feeling & Chakshusho Akulatvam Aswapna & - & - \\
\hline 5 & Pinkish, reddish or purplish rash & $\begin{array}{c}\text { Tamra-Krushna-Raktavarni Utsedha } \\
\text { Srava }\end{array}$ & - & Atilohita \\
\hline 6 & Rapid progression & - & Drutagati & Drutagati \\
\hline 7 & Burning sensation all over body & Ati Antardaha & Daha Bahula & - \\
\hline 8 & "Raw" areas of skin those are painful. & Sambhedana & $\begin{array}{l}\text { Prabheda } \\
\text { Bahula }\end{array}$ & - \\
\hline \multirow[t]{2}{*}{9} & \multirow[t]{2}{*}{ Skin begins to blister and peel (detach) } & Sphotaka & Sphota Bahula & - \\
\hline & & Achirapaki & Paka Bahula & - \\
\hline
\end{tabular}

\section{DISCUSSION}

During Ayurveda practice we have to deal with many prediagnosed cases of contemporary medicine, which can be considered as 'anuktavyadhi'. Clinical assessment of these anuktavyadhi should be done on the basis of Ayurvediya Siddhanta and Parikshana paddhati for sampraptiparakadhyayana as well as chikitsa vinishchaya. In Ayurveda, hypersensitivity or allergic manifestation is mentioned under the concept of Satmya-asatmya. It manifests due to exposure to Asatmya ahara-vihara-aushadha and contact with different poisonous materials (allergens). Acharya Charaka has clearly mentioned the etiopathogenesis behind the manifestation of Asatmya ahara-viharajanya vyadhi ${ }^{13}$. Almost all the Samhitas of Ayurveda support to the fact that pradnyaparadha is the root cause for manifestation of any kind of disease. As Acharya Vagbhata says heena/ati/mithya yoga of Shareerika, Vachika and Manas karma along with Asatmyasanyoga and kala is responsible for dosha prakopa to take place in the body ${ }^{14}$.

Here, effort has been made to establish a standard naidanik protocol for studying such anuktavyadhi by correlating vyadhi ghataka. The knowledge of hetu-linga, Upashaya along with chikitsa of any disease can be elaborated on the basis of chikitsa sutra. The chikitsa sutra for anuktavyadhi clearly emphasizes that chikitsa of such vyadhis should be done according to dosha, ling observed $^{15}$. Therefore, any of the disease should be diagnosed on the basis of vruddhi-kshaya lakshana of vitiated dosha and doshapratyanika chikitsa should be implemented. Also elicitation of detail history about hetu sevana would be beneficial in execution of hetupratyanika chikitsa and early control on disease. On the basis of Purvarupa and rupa observed in the patient vyadhipratyanika chikitsa should be adopted.

\section{CONCLUSION}

Stevens-Johnson syndrome is a rare, emergency disorder of skin and mucous membrane that occurs secondary to use of certain drugs (Allergens). In this case of Stevens-Johnson syndrome, after studying Nidanapanchaka, parameters were found to be matched with 'Pittaja Visarpa'.

It is a need of time to study such rare diseases in Ayurvedic perspective to develop diagnostic and curative protocols to overcome limitations of contemporary medical science. Hence, anuktavyadhi, like Stevens-Johnson syndrome, should be diagnosed and treated on the basis of Panchanidanatmak understanding of dosha-dushya Vikriti found in patient.

\section{Consent and ethical statement}

Present study was carried out in accordance with ethical principles by following the International Conference of Harmonization-Good Clinical Practices Guidelines (ICH-GCP).

\section{REFERENCES}

1. French LE. Toxic epidermal necrolysis and Stevens Johnson syndrome: Our current understanding. Allergol Int 2006; 55(1): 9-16.

2. Stevens-Johnson syndrome/toxic epidermal necrolysis Genetic Home References Statistics of SJS. Available from: https://ghr.nlm.nih.gov/condition/stevens-johnsonsyndrome-toxic-epidermal-necrolysis\#statistics

3. Castana O., Rempelos G., Anagiotos G., Apostolopoulou C., Dimitrouli A., Alexakis D. Stevens-Johnson Syndrome: A Case Report. Annals of Burns and Fire Disasters 2009; 22(3): 147.

4. Gurav Santosh Kishor, SameekshaSahni, Sapate Suresh M, G. P. Ram Reddy. Clinical Evaluation of Navakarshika Guggulu on Sheetapitta (Chronic Urticaria). International Journal of Pharmaceutical and Phytopharmacological Research 2012, 2. ISSN (Online) 2249 - 6084 (ICV-5.09): 196-201.

5. Agnivesha. Charaka Samhita elaborated by Charaka and Dridhabala with Ayurveda-Dipika Commentary by Chakrapanidatta, edited by Vaidya Yadavaji Trikamji Acharya. Chaukhambha Surbharati Prakashan Varanasi. Sutra sthana 26/81. p. 491.

6. Agnivesha. Charaka Samhita elaborated by Charaka and Dridhabala with Ayurveda-Dipika Commentary by Chakrapanidatta, edited by Vaidya Yadavaji Trikamji Acharya. Chaukhambha Surbharati Prakashan Varanasi. Chikitsa sthana 21/20. p. 559.

7. Agnivesha. Charaka Samhita elaborated by Charaka and Dridhabala with Ayurveda-Dipika Commentary by Chakrapanidatta, edited by Vaidya Yadavaji Trikamji Acharya. Chaukhambha Surbharati Prakashan Varanasi. Chikitsa sthana 21/11. p. 559.

8. Sushruta. Sushruta Samhita elaborated with Nibandha Sangraha Commentary by Dalhanacharya, edited by Vaidya Yadavaji Trikamji Acharya. Chaukhambha Sanskrit Sansthan Varanasi. Reprinted; 2011, Nidana sthana 10/3. p. 267.

9. Dr. Ganesh Krushna Garde. Vagbhata krut Ashtanga Hridaya, Sartha Vagbhata. Chaukhambha Surabharati Prakashan Varanasi. Nidana Sthana 13/44-45. p. 203.

10. Agnivesha. Charaka Samhita elaborated by Charaka and Dridhabala with Ayurveda-Dipika Commentary by Chakrapanidatta, edited by Vaidya Yadavaji Trikamji Acharya. Chaukhambha Surbharati Prakashan Varanasi. Chikitsa sthana 21/ 32. p. 560. 
11. Sushruta. Sushruta Samhita elaborated with Nibandha Sangraha Commentary by Dalhanacharya, edited by Vaidya Yadavaji Trikamji Acharya. Chaukhambha Sanskrit Sansthan Varanasi. Reprinted; 2011. Nidana sthana 10/5. p. 267.

12. Dr. Ganesh Krushna Garde. Vagbhata krut Ashtanga Hridaya, Sartha Vagbhata. Chaukhambha Surabharati Prakashan Varanasi. Nidana Sthana 13/48. p. 203.

13. Agnivesha. Charaka Samhita elaborated by Charaka and Dridhabala with Ayurveda-Dipika Commentary by Chakrapanidatta, edited by Vaidya Yadavaji Trikamji Acharya. Chaukhambha Surbharati Prakashan Varanasi. Sutra sthana 26/81. p. 149.

14. Dr. Ganesh Krushna Garde. Vagbhata krut Ashtanga Hridaya, Sartha Vagbhata. Chaukhambha Surabharati Prakashan Varanasi. Sutra Sthana 12/35. p. 57.
15. Sushruta. Sushruta Samhita elaborated with Nibandha Sangraha Commentary by Dalhanacharya, edited by Vaidya Yadavaji Trikamji Acharya. Chaukhambha Sanskrit Sansthan Varanasi. Reprinted; 2011. Sutra sthana 35/23. p. 133.

\section{Cite this article as:}

Vasudha Sunil Umate and Ashish Y. Gotmare. Panchanidanatmak Adhyayana of Stevens-Johnson Syndrome: A Case Study. Int. J. Res. Ayurveda Pharm. 2020;11(4):28-32 http://dx.doi.org/10.7897/2277-4343.110483

Source of support: Nil, Conflict of interest: None Declared

Disclaimer: IJRAP is solely owned by Moksha Publishing House - A non-profit publishing house, dedicated to publishing quality research, while every effort has been taken to verify the accuracy of the content published in our Journal. IJRAP cannot accept any responsibility or liability for the site content and articles published. The views expressed in articles by our contributing authors are not necessarily those of IJRAP editor or editorial board members. 